\title{
Canopy Position Influences CIELAB Coordinates of Peach Color
}

\author{
Bernard B. Bible and Suman Singha \\ Department of Plant Science, University of Connecticut, Storrs, \\ CT 06269-4067
}

Additional index words. Prunus persica, fruit color, calorimeter

\begin{abstract}
Differences in color development between exposed and shaded fruit during the growing season were determined for 'Loring' and 'Raritan Rose' peach (Prunus persica L. Batsch). The surface color of fruit exposed to sunlight in the upper canopy, and in the shade in the lower canopy, was measured with a tristimulus calorimeter, and $L^{*} a^{*} b^{*}$ values were recorded for each fruit from 17 July through harvest. Color changes $\left(\Delta \mathrm{E} *{ }_{\mathrm{abb}}\right)$ during maturation for both cultivars at either canopy position were characterized by large changes in hue $\left(\Delta \mathrm{H}^{*}{ }_{\mathrm{ab}}\right)$ and lesser changes in lightness $\left(\Delta \mathrm{L}^{*}{ }_{\mathrm{ab}}\right)$ and chroma $\left(\Delta \mathrm{C}^{*}{ }_{\mathrm{ab}}\right)$. Upper canopy fruit of both cultivars were redder and darker than the lower canopy fruit initially and at harvest. Flesh firmness for 'Loring' and 'Raritan Rose' tended to correlate with color change from initial sampling to harvest.
\end{abstract}

Information is meager on peach fruit color development during maturation at different canopy positions, although this may be an important consideration in designing peach orchards for efficient light use. This study determined the differences in peach fruit color development at two canopy positions.

Received for publication 28 Sept. 1992. Accepted for publication 8 June 1993. Storrs Agricultural Experiment Station scientific contribution 1457. The cost of publishing this paper was defrayed in part by the payment of page charges. Under postal regulations, this paper therefore must be hereby marked advertisement solely to indicate this fact.
'Loring' and 'Raritan Rose' fruit were sampled from 8-year-old trees (height $3.4 \mathrm{~m}$ ) at the university orchard. Trees trained to a modified central leader were spaced $4.9 \times 3.1$ $m$ with rows oriented east-west. CIELAB coordinates were measured with a Minolta CR-200b colorimeter (Minolta, Ramsey, N.J.) for 10 tagged fruit on each of three trees of each cultivar. Of the 10 fruit, five were exposed to sunlight in the upper canopy (height $>2.2 \mathrm{~m}$ ), and five were in the shade in the lower canopy. There were three single-tree replicates per canopy position and per cultivar in a randomized complete block design.
The tagged fruit $L^{*} a^{*} b^{*}$ values were measured at the midpoint between the stem and the stylar end. Measurements were made at about the same marked location on each fruit at intervals between 17 July and harvest. The calorimeter was calibrated at illuminant $\mathrm{C}$ with a white standard. We calculated other CIELAB coordinates from the $\mathrm{L}^{*} \mathrm{a}^{*} \mathrm{~b}^{*}$ values, including hue angle $\left(\tan ^{-1} \mathrm{~b}^{*} / \mathrm{a}^{*}\right)$ and chroma $\left(\sqrt{ } a^{*^{2}}+b^{* 2}\right)$. Color differences $\left(\Delta E *{ }_{a b}\right)$ and hue differences $\left(\Delta \mathrm{H}^{*}{ }_{\mathrm{ab}}\right)$ between pairs of peach samples were computed as $\Delta \mathrm{E} *{ }_{\text {ab }}=$ $\sqrt{\Delta} \mathrm{L}^{*^{2}}+\Delta \mathrm{a}^{*^{2}}+\Delta \mathrm{b}^{*^{2}}$, and $\Delta \mathrm{H}^{*}=2 \sqrt{ }\left(\mathrm{C}^{*} 1^{\mathrm{ab}} \times\right.$ $\left.C^{*} 2\right) \times \sin (\Delta H / 2)\left(\right.$ Sève, 1991), where $C^{*} 1$ and $\mathrm{C}^{*} 2$ represent the chromas of pair members, and $\Delta \mathrm{H}$ is the hue angle difference between the pair members.

Photosynthetic photon flux (PPF) near the exposed fruit cheek was measured in the upper and lower canopies between 1100 and $1200 \mathrm{HR}$ on clear, sunny days ( 17 July and 5 and 7 Aug.) with a Lambda LI-905 quantum sensor with a LI-COR LI 185A quantum/radiometer/photometer (LI-COR, Lincoln, Neb.).

Based on ground color, fruit was harvested from the upper and lower canopies on 12 and 19 Aug., respectively, for 'Loring'; and on 5 and 9 Aug., respectively, for 'Raritan Rose'. Following harvest, flesh firmness was measured on both sides of each fruit using a penetrometer equipped with an 8-mm plunger. Soluble solids concentration (SSC) was determined with a hand-held refractometer. The relationship of CIELAB coordinates to flesh firmness and SSC at harvest was tested for a linear model.

During maturation, color changes $(\Delta \mathrm{E} *{ })$ for fruit of both cultivars at both canopy posi- 
Table 1. CIELAB color differences for two peach cultivars during maturation at two canopy positions. Initial blush color readings were taken 17 July.

\begin{tabular}{llrrrr}
\hline & & \multicolumn{3}{c}{$\mathrm{CIELAB}$ coordinates $^{2}$} \\
\cline { 3 - 6 } Cultivar & \multicolumn{1}{c}{ Location and color } & $\Delta \mathrm{E}^{*}{ }_{\mathrm{ab}}$ & $\Delta \mathrm{H}_{\mathrm{ab}}^{*}$ & $\Delta \mathrm{L}^{*}$ & $\Delta \mathrm{C}^{*}{ }_{\mathrm{ab}}$ \\
\hline Loring & Upper canopy: harvest vs. initial color & 21.6 & -21.0 & 3.1 & 3.8 \\
& Lower canopy: harvest vs. initial color & 22.2 & -21.1 & 5.3 & 4.4 \\
& Initial color: upper vs. lower canopy & 15.1 & -10.6 & -8.9 & -5.2 \\
& Final color: upper vs. lower canopy & 19.8 & -15.4 & -11.1 & -5.7 \\
Raritan & & & & & \\
Rose & Upper canopy: harvest vs. initial color & 35.2 & -34.0 & -5.7 & -5.4 \\
& Lower canopy: harvest vs. initial color & 28.9 & -27.6 & -2.6 & -7.8 \\
& Initial color: upper vs. lower canopy & 8.6 & -7.1 & -4.9 & 0.4 \\
& Final color: upper vs. lower canopy & 13.9 & -11.2 & -8.0 & 1.9 \\
\hline
\end{tabular}

${ }^{\mathrm{z}} \Delta \mathrm{E}^{*}{ }_{\mathrm{ab}}$, change in color; $\Delta \mathrm{H}^{*}{ }_{\mathrm{ab}}$, change in hue; $\Delta \mathrm{L}^{*}$, change in lightness; $\Delta \mathrm{C}^{*}{ }_{\mathrm{ab}}$, change in chroma.

Table 2. Correlation coefficients $(r)$ of CIELAB coordinates of fruit color for upper and lower canopy fruit with flesh firmness and soluble solids concentration (SSC) of two peach cultivars. Initial blush color readings taken 17 July.

\begin{tabular}{|c|c|c|c|c|}
\hline \multirow[b]{3}{*}{$\begin{array}{l}\text { CIELAB } \\
\text { coordinates }^{2}\end{array}$} & \multicolumn{4}{|c|}{ Correlation coefficients of color } \\
\hline & \multicolumn{2}{|c|}{ Loring } & \multicolumn{2}{|c|}{ Raritan Rose } \\
\hline & $\begin{array}{c}\text { Flesh } \\
\text { firmness }\end{array}$ & SSC & $\begin{array}{c}\text { Flesh } \\
\text { firmness }\end{array}$ & SSC \\
\hline \multicolumn{5}{|c|}{ Blush color at harvest } \\
\hline Hue angle & $0.41^{*}$ & $-0.41^{*}$ & $0.52^{* *}$ & $-0.45^{*}$ \\
\hline $\mathrm{L}^{*}$ & 0.16 & $-0.50^{4 *}$ & 0.32 & -0.25 \\
\hline $\mathrm{C}^{*}{ }_{\mathrm{ab}}$ & -0.21 & $-0.60^{* * *}$ & -0.36 & 0.25 \\
\hline \multicolumn{5}{|c|}{ Blush color difference (harvest color-initial color) } \\
\hline$\Delta \mathbf{E}^{*}{ }_{\mathrm{ab}}$ & $-0.73^{* * *}$ & -0.06 & $-0.63^{* * *}$ & 0.35 \\
\hline$\Delta \mathbf{H}^{*}{ }_{a b}$ & $0.70^{* * *}$ & 0.03 & $0.61^{* * *}$ & -0.34 \\
\hline$\Delta \mathrm{L}_{\mathrm{ab}}^{*}$ & $0.47^{* *}$ & -0.13 & $0.39^{*}$ & -0.25 \\
\hline$\Delta C^{*}{ }_{a b}$ & 0.35 & -0.18 & 0.05 & 0.08 \\
\hline
\end{tabular}

tions were characterized by large changes in hue $\left(\Delta \mathrm{H}^{*}{ }_{\text {ab }}\right)$ and lesser changes in lightness $\left(\Delta \mathrm{L}^{*}\right)$ and chroma $\left(\Delta \mathrm{C}^{*}{ }_{\mathrm{ab}}\right)$ (Table 1$)$. Initially and at harvest, upper canopy fruit of both cultivars were redder $\left(-\Delta \mathrm{H}^{*}{ }_{\text {ab }}\right)$ and darker $\left(-\Delta \mathrm{L}^{*}\right)$ than lower canopy fruit. Interestingly, much of this color difference between fruit in the upper and lower canopies had already developed by the initial reading on 17 July.

During maturation, fruit surface hue angle change is consistent with decreasing chlorophyll and increasing anthocyanin. Singha and Townsend (1989) reported that differences in the CIELAB coordinates of leaf color could be ascribed largely to differences in chlorophyll concentration. The lower $\mathrm{L} *$ readings for upper canopy fruit vs. lower canopy fruit at harvest could be explained by higher levels of anthocyanin in the upper canopy fruit (Singha et al., 1991).
The PPF values in our orchard's upper canopy ranged from 1360 to $1580 \mu \mathrm{mol} \cdot \mathrm{s}^{-1}$ compared to 23 to $58 \mu \mathrm{mol} \cdot \mathrm{s}^{-1}$ in the lower canopy. Erez and Flore (1986) reported that exposure to full sunlight is essential for maximum red pigment development in peach fruit. Our results are consistent with the proposition that shading reduces red pigmentation in peach fruit because of reduced anthocyanin synthesis.

For both cultivars, flesh firmness tended to correlate with color change from initial sampling to harvest $\left(\Delta \mathrm{E} *{ }_{a}, \Delta \mathrm{H}^{*}{ }_{\mathrm{a}}, \Delta \mathrm{L}^{*}\right)$ (Table 2). The SSC correlated with color at harvest (hue angle, $\mathrm{L}^{*}, \mathrm{C}^{*}{ }_{\mathrm{ab}}$ ), especially for 'Loring'. Hue angle of the fruit surface at harvest correlated with flesh firmness for both cultivars in the lower canopy, but for neither cultivar in the upper canopy (data not shown). Perhaps differences in the surface color of the fruit cannot be ascribed to differences in skin pigmentation only, particularly for shaded fruit. Shaded fruit have less red pigmentation at the fruit surface, which may allow underlying flesh color or ground color to come through. Our results show the extent to which lack of uniformity of maturity in peach is exacerbated by canopy position.

\section{Literature Cited}

Erez, A. and J. Flore. 1986. The quantitative effect of solar radiation on 'Redhaven' peach fruit skin color. HortScience 21:1424-1426.

Sève, R. 1991. New formula for the computation of CIE 1976 hue difference. Color Res. Applications 16:217-218.

Singha, S., T. Baugher, E. Townsend, and M. D'Souza. 1991. Anthocyanin distribution in 'Delicious' apples and the relationship between anthocyanin concentration and chromaticity values. J. Amer. Soc. Hort. Sci. 116:487-499.

Singha, S. and E. Townsend. 1989. Relationship between chromaticity values and chlorophyll concentration in apple, grape, and peach leaves. HortScience 24:1034. 